\title{
Skills Level of Agriculture Technology School Students
}

\author{
A. P. Dangore ${ }^{1}$, P. K. Wakle ${ }^{1}$ and A. G. Raut ${ }^{2^{*}}$ \\ ${ }^{1}$ Department of Extension Education, ${ }^{2}$ College of Horticulture, Post Graduate Institute, \\ Dr.PDKV, Akola, India \\ *Corresponding author
}

\section{A B S T R A C T}

\section{Keywords}

Skills, Agriculture Technology School, Students

\section{Article Info}

Accepted:

24 October 2020

Available Online:

10 November 2020
The present study on "Skills of Agriculture Technology School students" was conducted in Akola and Amravati districts of Maharashtra state. The exploratory research design of social research was used. In all, 120 respondents were selected by random sampling method. The data was collected with the help of questionnaire and statistically analyzed. The findings of the present study revealed that, majority of the respondents $(57.50 \%)$ belonged to male category, $(40.83 \%)$ were other backward class category, $(65.84 \%)$ were having medium family education $(40.00 \%)$ were having their parents main occupation as agriculture, $(30.00 \%)$ belonged to semi-medium family land holding (2.01 to 4.00 ha), $(48.33 \%)$ were belonged to medium family income group, $45.00 \%$ respondents were having medium level of participation in extra-curricular activities, (67.50\%) had rural family background, whereas, majority of the students $(39.17 \%)$ had secured first class in academic performance.. In case of skills, majority of the students $(56.67 \%)$ had medium level of skills. Further it was reported that, family education, parental occupation, family land holding, family income, participation in extra-curricular activities, family background, academic performance had positive and significant relationship with their Skill of different subjects of ATS. In case of gender and caste of the students, it was found to be negatively non-significant with their Skill of different subjects of ATS.

\section{Introduction}

India is passing through third stage of demographic growth rate, but also an extremely large existing size of population. Thus, unless this tremendous increase in the population is curbed, the economic development of the nation will be curtailed on account of its adverse effect on the national income, food supply, unemployment and the capital formation. Looking to increased population, the present need is to engage the agriculture students in agricultural production process and allied sectors. In Indian situation agriculture has been providing basis for many diversified industries and is professed by a big majority of working population.

To bring more perfection in agriculture, for increasing productivity it was thought necessary by policy makers to establish Agricultural Universities in the country. Agricultural education in India is very important in a sense that nations economy 
mostly depends upon agriculture. It is observed that most of the students coming out of agricultural universities do not meet the requirements of knowledge and skills. Agriculture is applied science and hence vigorous practical training and continuous updating of knowledge and skills is also necessary.

Basic education will also ensure that village youths would be better oriented for sharing responsibilities in the field of rural development and throw up the right kind of leadership and help, to some extent, in reversing the process of drift of talent from the villages to the cities, which is so important. Agriculture education upto diploma level will better promote rural leadership and fit rural youth for self employment. There should be adequate provision for agricultural education and understanding of the place of agriculture in life of the rural communities.

Lower Agriculture Education is independent education branch working separately in agricultural universities since many years. Agriculture schools under agricultural universities are offering two years diploma course in agriculture. Boys and girls from rural farm families are seeking admission to this course on large scale.

The course curriculum of the agriculture schools consists of soil science, crop production, Animal Husbandry and dairy Science, Horticulture, economics and Extension Education. The course is mostly practical oriented and provide agricultural education to the grass root level farming community of country which is expected to results in increased farm production. These agriculture students are the youths from agricultural families. After completing this course they are supposed to apply their knowledge and skill to agriculture and improve the farm situation. They can also play an important role in agriculture entrepreneurship development (Kalantri and Khonde, 2003).

Considering the importance of lower education in Agricultural University the present study has been undertaken.

The main objectives of this includes to study the profile of the Agriculture Technology School students. To study the extent of Skill possessed by the Agriculture Technology School students. And also to study the relationship of profile of Agriculture Technology School students with Skill.

\section{Materials and Methods}

Agriculture technology school from Amravati and Akola district was purposively selected for the study. Total 120 Agriculture technology school students were selected for the research purpose. The questionnaire was constructed by formulating relevant questions in accordance with objectives of the study. The questionnaire included questions pertaining to gender, caste, family education, parental occupation, family land holding, family income, participation in extracurricular activities, family background, academic performance as well as knowledge. The information from the respondents was collected by personal visit and their responses were considered for the purpose of present study. Data was collected. Mean, S.D. and coefficient of correlation methods were used for analysis of the data.

\section{Results and Discussion}

The results obtained from the analysis of the data in accordance of the study objectives along with the logical discussion has been given to interpret the observed phenomena. 
Table 1 shows that 57.50 percent students were male and remaining 42.50 percent students were female. It was observed that 40.83 per cent of the students were from other backward class, Majority of the students of about 65.84 per cent were having the medium level of the family education. It clearly indicated that majority of the students studying in Agriculture technology schools belonged to medium educated families. It was also observed that about 40.00 per cent of students were having their parent's main occupation as only agriculture (Table 2 and $3)$.

Table.1 Socio personal characteristics of Agriculture Technology School students ( $\mathrm{N}=120)$

\begin{tabular}{|c|c|c|c|}
\hline \multirow{2}{*}{$\begin{array}{l}\text { Sr. } \\
\text { No. }\end{array}$} & \multirow{2}{*}{ Variables and category } & \multicolumn{2}{|c|}{ Respondents $(\mathrm{N}=\mathbf{1 2 0})$} \\
\hline & & Number & Percentage \\
\hline 1. & $\begin{array}{l}\text { Gender } \\
\text { Male } \\
\text { Female }\end{array}$ & $\begin{array}{l}69 \\
51 \\
\end{array}$ & $\begin{array}{l}\mathbf{5 7 . 5 0} \\
42.50\end{array}$ \\
\hline 2. & $\begin{array}{l}\text { Caste } \\
\text { General(Open) } \\
\text { Other backward class } \\
\text { Schedule caste } \\
\text { Schedule tribes } \\
\text { VJ/NT }\end{array}$ & $\begin{array}{l}05 \\
49 \\
26 \\
18 \\
22\end{array}$ & $\begin{array}{l}04.17 \\
40.83 \\
21.67 \\
15.00 \\
18.33\end{array}$ \\
\hline 3. & $\begin{array}{l}\text { Family education } \\
\text { Low } \\
\text { Medium } \\
\text { High }\end{array}$ & $\begin{array}{l}19 \\
79 \\
22\end{array}$ & $\begin{array}{l}15.83 \\
65.84 \\
18.33\end{array}$ \\
\hline 4. & $\begin{array}{l}\text { Parental occupation } \\
\text { Agriculture +Labour } \\
\text { Agriculture } \\
\text { Agriculture + Allied occupation } \\
\text { Agriculture + Business } \\
\text { Agriculture + Service }\end{array}$ & $\begin{array}{l}41 \\
\mathbf{4 8} \\
16 \\
09 \\
06\end{array}$ & $\begin{array}{l}34.17 \\
40.00 \\
13.33 \\
07.50 \\
05.00\end{array}$ \\
\hline 5 & $\begin{array}{l}\text { Family land holding } \\
\text { Marginal (Up to } 1 \text { ha) } \\
\text { Small (1.01 to } 2.00 \mathrm{ha}) \\
\text { Semi-medium }(2.01 \text { to } 4.00 \text { ha) } \\
\text { Medium ( } 4.01 \text { to } 10.00 \text { ha) } \\
\text { Large (Above } 10.00 \text { ha) }\end{array}$ & $\begin{array}{l}28 \\
21 \\
36 \\
33 \\
02\end{array}$ & $\begin{array}{l}23.33 \\
17.50 \\
30.00 \\
27.50 \\
01.67\end{array}$ \\
\hline 6 & $\begin{array}{l}\text { Family income } \\
\text { Low } \\
\text { Medium } \\
\text { High }\end{array}$ & $\begin{array}{l}29 \\
\mathbf{5 8} \\
33\end{array}$ & $\begin{array}{l}24.17 \\
48.33 \\
27.50\end{array}$ \\
\hline 7 & $\begin{array}{l}\text { Participation in extracurricular activities } \\
\text { No participation } \\
\text { Low participation } \\
\text { Medium participation } \\
\text { High participation }\end{array}$ & $\begin{array}{l}09 \\
\mathbf{5 4} \\
36 \\
21\end{array}$ & $\begin{array}{l}07.50 \\
45.00 \\
30.00 \\
17.50\end{array}$ \\
\hline 8 & $\begin{array}{l}\text { Family background } \\
\text { Rural } \\
\text { Urban }\end{array}$ & $\begin{array}{l}81 \\
39\end{array}$ & $\begin{array}{l}\mathbf{6 7 . 5 0} \\
\mathbf{3 2 . 5 0}\end{array}$ \\
\hline 9 & $\begin{array}{l}\text { Academic performance } \\
\text { Pass }(35.00 \text { to } 49.99) \\
\text { Second class }(50.00 \text { to } 59.99) \\
\text { First class }(60.00 \text { to } 74.99) \\
\text { Distinction }(75.00 \text { and above })\end{array}$ & $\begin{array}{l}17 \\
37 \\
47 \\
19\end{array}$ & $\begin{array}{l}14.17 \\
30.83 \\
39.17 \\
15.83\end{array}$ \\
\hline
\end{tabular}


Table.2 Overall Distribution of the respondents according to their Skill by mean Skill index formula

\begin{tabular}{|c|l|c|c|}
\hline \multirow{2}{*}{ Sl. No. } & \multirow{2}{*}{ Skill level } & \multicolumn{2}{|c|}{ Respondents $(\mathbf{n = 1 2 0})$} \\
\cline { 3 - 4 } & & Frequency & Percentage \\
\hline $\mathbf{1}$ & Low & 25 & 20.83 \\
\hline $\mathbf{2}$ & Medium & 68 & 56.67 \\
\hline $\mathbf{3}$ & High & 27 & 22.50 \\
\hline & Total & $\mathbf{1 2 0}$ & $\mathbf{1 0 0 . 0 0}$ \\
\hline
\end{tabular}

Table.3 Statement wise distribution of the ATS Students on the basis of their Skill

\begin{tabular}{|c|c|c|c|}
\hline \multirow[t]{2}{*}{ Sl. No. } & \multirow[t]{2}{*}{ Skills } & \multicolumn{2}{|c|}{ Respondents $(\mathrm{N}=120)$} \\
\hline & & Yes & No \\
\hline 1 & Overhead projector handling & $\begin{array}{c}12 \\
(10.00)\end{array}$ & $\begin{array}{c}108 \\
(90.00)\end{array}$ \\
\hline 2 & Soil sampling & $\begin{array}{c}114 \\
(95.00)\end{array}$ & $\begin{array}{c}06 \\
(05.00)\end{array}$ \\
\hline 3 & Handling of sprayer & $\begin{array}{c}84 \\
(70.00)\end{array}$ & $\begin{array}{c}36 \\
(30.00)\end{array}$ \\
\hline 4 & Budding on rose & $\begin{array}{c}91 \\
(75.83)\end{array}$ & $\begin{array}{c}29 \\
(24.17)\end{array}$ \\
\hline 5 & Seed treatment & $\begin{array}{c}110 \\
(91.67)\end{array}$ & $\begin{array}{c}10 \\
(08.33) \\
\end{array}$ \\
\hline 6 & Azolla production technology & $\begin{array}{c}54 \\
(45.00)\end{array}$ & $\begin{array}{c}66 \\
(55.00)\end{array}$ \\
\hline 7 & Preparation of vermicompost & $\begin{array}{c}82 \\
(68.33)\end{array}$ & $\begin{array}{c}38 \\
(31.67)\end{array}$ \\
\hline 8 & Prepare $5 \%$ neem extract & $\begin{array}{c}87 \\
(72.50)\end{array}$ & $\begin{array}{c}33 \\
(27.50)\end{array}$ \\
\hline 9 & Preparation of compost by NADEP & $\begin{array}{c}59 \\
(49.17)\end{array}$ & $\begin{array}{c}61 \\
(50.83)\end{array}$ \\
\hline 10 & Checking of seed germination potential & $\begin{array}{c}104 \\
(86.67)\end{array}$ & $\begin{array}{c}16 \\
(13.33)\end{array}$ \\
\hline 11 & Seedbed preparation & $\begin{array}{c}89 \\
(74.17)\end{array}$ & $\begin{array}{c}31 \\
(25.83)\end{array}$ \\
\hline 12 & Preparation of ridges and furrows & $\begin{array}{c}73 \\
(60.83)\end{array}$ & $\begin{array}{c}47 \\
(39.17)\end{array}$ \\
\hline 13 & Preparation of milk products eg. Basundi, Khawa & $\begin{array}{c}112 \\
(93.33)\end{array}$ & $\begin{array}{c}8 \\
(06.67)\end{array}$ \\
\hline 14 & Handling drip and sprinkler irrigation system & $\begin{array}{c}78 \\
(65.00)\end{array}$ & $\begin{array}{c}42 \\
(35.00)\end{array}$ \\
\hline 15 & Preparation of Bordeaux paste, Bordeaux mixture & $\begin{array}{c}71 \\
(59.17)\end{array}$ & $\begin{array}{c}49 \\
(40.83)\end{array}$ \\
\hline 16 & Preparation of nursery & $\begin{array}{c}68 \\
(56.67)\end{array}$ & $\begin{array}{c}52 \\
(43.33)\end{array}$ \\
\hline 17 & Grafting in fruit crop & $\begin{array}{c}88 \\
(73.33)\end{array}$ & $\begin{array}{c}32 \\
(26.67)\end{array}$ \\
\hline 18 & Method of fertilizer application of horticulture crop & $\begin{array}{c}82 \\
(68.33)\end{array}$ & $\begin{array}{c}38 \\
(31.67)\end{array}$ \\
\hline 19 & Preparation of papaya jam & $\begin{array}{c}92 \\
(76.67)\end{array}$ & $\begin{array}{c}28 \\
(23.33)\end{array}$ \\
\hline 20 & Seed production technology eg. Rouging, isolation distance & $\begin{array}{c}99 \\
(82.50)\end{array}$ & $\begin{array}{c}21 \\
(17.50)\end{array}$ \\
\hline
\end{tabular}


Table.4 Relationship between socio-economic characteristics and Skill

\begin{tabular}{|c|l|c|}
\hline Sl. No. & Independent variable & 'r' value \\
\hline $\mathbf{1}$ & Gender & $-0.0179^{\mathrm{NS}}$ \\
\hline $\mathbf{2}$ & Caste & $-0.0706^{\mathrm{NS}}$ \\
\hline $\mathbf{3}$ & Family education & $0.1989^{*}$ \\
\hline $\mathbf{4}$ & Parental occupation & $0.3167^{* *}$ \\
\hline $\mathbf{5}$ & Family Land holding & $0.2747^{* *}$ \\
\hline $\mathbf{6}$ & Family income & $0.2665^{* *}$ \\
\hline $\mathbf{7}$ & Participation in extracurricular activities & $0.7180^{* *}$ \\
\hline $\mathbf{8}$ & Family background & $0.3510^{* *}$ \\
\hline $\mathbf{9}$ & Academic performance & $0.6200^{* *}$ \\
\hline
\end{tabular}

It was revealed that about 30.00 per cent of the students were belonged to the semimedium family land holding and near about half of the students $(48.33 \%)$ were belonged to the medium family income group, while 45.00 per cent were having low level of participation in extra-curricular activities.

It was further observed that majority of the students of $(67.50 \%)$ were from rural background. This might be due to India's most of the population was lived in the rural areas. It was noted that 39.17 per cent of the students had secured first class.

\section{Overall Skill of ATS Students}

Agriculture technology school students play a vital role in diffusion of innovation among the farming community. It is presumed that students must know every skill in agriculture which they learn during their studies in Agriculture Technology School. They are expected to be proficient in various skills. The distribution of respondents according to skills has been presented below.

It is observed that 56.67 per cent of students had medium skills level whereas 22.50 per cent students had high skills achiever, only 20.83 per cent of students had low agricultural skills level.
It can be concluded that majority of the students of agriculture technology school had medium level of skills.

\section{Relational analysis}

Correlation analysis was carried out to find out as to whether the selected characteristics had any association with Skill of Agriculture Technology School Students. The coefficients of correlation of the personal and socioeconomic characters with Skill of Agriculture Technology School Students have been furnished in Table 4.

Regarding characteristics of Agriculture Technology School Students i.e. parental occupation, family land holding, family income, participation in extra-curricular activities, family background, academic performance had positive and significant relationship at 0.01 level of probability with Skill of Agriculture Technology School Students whereas, family education had positive and significant relationship at 0.05 level of probability.

Further, remaining characteristics of Skill of Agriculture Technology School Students such as gender and caste did not establish significant relationship with Skill of Agriculture Technology School Students. 


\section{References}

Babar, M. S. 2003. Agricultural knowledge and skill of agricultural school students. M.Sc. (Agri.) Thesis (Unpub.) Dr.PDKV, Akola.

Kadam, P.B. 2010. Learning style of Agriculture Technology School Students. M. Sc. Thesis (Unpub.) Dr.PDKV, Akola.

Kalantri, L. B. and S. R. Khonde. 2003. Training Needs of agricultural school students for entrepreneurship development. Annual Report of Research Work: 1-8.

Khoisnam, N. and S. D. Mukhopadhyay. 2018. Study of knowledge, skill and extent of participation of Self Help Group members in managing SHGs and income generating activities. Int. $J$.
Curr. Microbial. App. Sci. (2018) 7(1): 2270-2279.

Savita and Krishana Duhan 2012. Coparative assessment of adolescent's personality on the basis of socio-economic variables. Indian Journal of social research, vol. 53(5), PP: 409-418.

Shelke, R. A. 2017. Aspiration of agriculture polytechnic school students. M.Sc. (Agri.) Thesis (Unpub.), Dr.PDKV, Akola.

Subba, Ranjit and Siddhartha D. Mukhopadhyay. 2019. Impact of ATMA (Agricultural Technology Management Agency) in changing knowledge, skills and adoption behaviour of farmers in Sikkim. Int. J. Curr. Microbiol. App. Sci. (2019) 8(3): 1493-1505.

\section{How to cite this article:}

Dangore, A. P., P. K. Wakle and Raut, A. G. 2020. Skills Level of Agriculture Technology School Students. Int.J.Curr.Microbiol.App.Sci. 9(11): 3540-3545. doi: https://doi.org/10.20546/ijcmas.2020.911.423 